\title{
The Effect of Autosomal Dominant Polycystic Kidney Disease on Spirometric Parameters
}

\author{
๑ Tuba Elif Özler, ๑ Faruk Karandere*, ๑ Egemen Cebeci, ๑ Meltem Gürsu**, ๑ Barış Döner, \\ ๑ Abdullah Şumnu, ๑ Mustafa Sarı*** • Gülfidan Çakmak **** , ๑ Zeynep Karaali*, \\ ๑ Savaş Öztürk
}

University of Health Sciences Turkey, Istanbul Haseki Training and Research Hospital, Clinic of Nephrology, Istanbul, Turkey

*University of Health Sciences Turkey, Istanbul Haseki Training and Research Hospital, Clinic of Internal Medicine, Istanbul, Turkey

**Bezmialem Vakif University Faculty of Medicine, Department of Nephrology, Istanbul, Turkey

***University of Health Sciences Turkey, Istanbul Haseki Training and Research Hospital, Clinic of Cardiology, Istanbul, Turkey

$* * * *$ University of Health Sciences Turkey, istanbul Haseki Training and Research Hospital, Clinic of Chest Diseases, Istanbul, Turkey

\section{Abstract}

Aim: There is no enough data on pulmonary involvement in autosomal dominant polycystic kidney disease (ADPKD). The aim of this study is to examine pulmonary function test in patients with ADPKD with varying stages of renal function and to compare them with those in healthy controls.

Methods: Forty-six patients with ADPKD and 43 healthy control subjects were included in the study. Pulmonary function test was performed for each patient after routine physical examination and biochemical analysis.

Results: Age, gender, weight, height and smoking rate were similar in both groups. Seven patients (15.2\%) had restrictive pattern and one $(2.1 \%)$ had obstructive pattern in ADPKD group while one patient (2.3\%) had obstructive pattern and two (4.6\%) had restrictive pattern in the control group. The frequency of restrictive pattern was not significantly higher $(p=0.15)$, but forced vital capacity volume was significantly lower in the patient group ( $p=0.04)$.

Conclusion: Restrictive spirometric pattern was more prevalent in the patient group, but there was no statistically significant difference. It is thought that the difference may be statistically significant when the study is performed with kidney volume analysis and larger patient population.

Keywords: Autosomal dominant polycystic kidney disease, lung, pulmonary function test, spirometry

\section{Öz}

Amaç: Otozomal dominant polikistik böbrek hastalığında (ODPBH) akciğer tutulumu için literatürde yeterli veri yoktur. Bu çalışmanın amacı, ODPBH'nin ve farklı evrelerinini, solunum fonksiyon testleri üzerine etkisini incelemektir.

Yöntemler: Kırk altı ODPBH hastası ve 43 sağlıklı kontrol olgusu çalışmaya dahil edildi. Her olgu için rutin fizik muayene ve biyokimyasal analizden sonra solunum fonksiyon testleri yapıldı.

Bulgular: Yaş, cinsiyet, kilo, boy ve sigara içme oranı her iki grupta benzerdi. Otozomal dominant polikistik böbrek hastalığı grubunda yedi hastada $(\% 15,2)$ restriktif patern, bir hastada $(\% 2,1)$ obstrüktif patern, kontrol grubunda bir hastada $(\% 2,3)$ obstrüktif patern, iki hastada $(\% 4,6)$ restriktif patern tespit edildi. Restriktif patern, iki grupta benzer olmakla birlikte $(p=0,15)$, zorlu vital kapasite hacmi hasta grubunda anlamlı olarak düşüktü $(p=0,04)$.

Sonuç: Hasta grubunda restriktif spirometrik patern daha sık görüldü, ancak istatistiksel olarak anlamlı bir fark yoktu. Çalışma böbrek hacim analizi ve daha büyük hasta popülasyonu ile yapıldığında, farkın istatistiksel olarak anlamlı olabileceği düşünülmektedir.

Anahtar Sözcükler: Otozomal dominant polikistik böbrek hastalığı, akciğer, solunum fonksiyon testi, spirometri
Address for Correspondence/Yazışma Adresi: Tuba Elif Özler, University of Health Sciences Turkey, İstanbul Haseki Training and Research Hospital, Clinic of Nephrology, İstanbul, Turkey E-mail: telifsenel@gmail.com ORCID: orcid.org/0000-0002-8637-3582

Received/Geliş Tarihi: 25 August 2020 Accepted/Kabul Tarihi: 22 October 2020

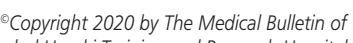
istanbul Haseki Training and Research Hospital The Medical Bulletin of Haseki published by Galenos Yayınevi. ${ }^{8}$ Telif Hakkı 2020 istanbul Haseki Eğitim ve Araştırma Hastanesi Haseki Tıp Bülteni, Galenos Yayınevi tarafından yayınlanmıştır. 


\section{Introduction}

Autosomal dominant polycystic kidney disease (ADPKD), the most common hereditary kidney disorder, may causes pathologies in several systems such as cardiovascular, gastrointestinal, urogenital, and central nervous systems beside the kidneys $(1,2)$. Although cystic and non-cystic extrarenal involvement of ADPKD in various organs are defined, pulmonary involvement has not been clarified yet (3-6). In a study by Moua et al. (6), patients with ADPKD were compared with those having chronic kidney disease (CKD), and bronchiectasis was observed more frequently in the ADPKD group, and it was frequently found to be localized in the lower lobes. One third of the patients, who were detected to have radiologic bronchiectasis, were symptomatic. Smoking was identified as an independent risk factor for the development of bronchiectasis in the ADPKD group (6). Mutations in polycystin genes show their direct effects on renal primary cilia. Polycystins are also expressed in the cilia of airway epithelial cells and airway smooth muscle cells $(4,7)$. As a result, functional abnormalities in polycystins may decrease mucociliary clearance resulting in radiologic bronchiectasis (4).

The reason for most extrarenal involvement is the reflection of abnormalities in the collagen and extracellular matrix to all systems. Cardiovascular complications are more common in patients with ADPKD than in the general population and are the most important causes of death. These complications include early-onset hypertension, left ventricular hypertrophy, pericardial effusion, and heart valve diseases (3). Hypertension is the main risk factor for the development of early cardiovascular disease. Left ventricular hypertrophy is a major cause of mortality and morbidity (8-10).

We aimed to examine pulmonary function tests in patients with ADPKD and to compare the results with the healthy control group. We also investigated its relationship with kidney function test and respiratory function test.

\section{Methods}

This study was a single-center study, which enrolled patients over 18 years of age followed in our nephrology outpatient clinic. We compared the pulmonary function tests between patients with ADPKD and healthy controls. The study included forty-six patients and 43 healthy volunteers. Patients younger than 18 years of age, with acute respiratory system infection, history of any malignancy in remission, stage 3-4 heart failure, morbid obesity, connective tissue disorders, restrictive or obstructive lung disorder, neuromuscular disease, open lung surgery or abdominal surgery, decompensated liver disease, pleural and/or pericardial effusion, or nephrotic syndromes, those using immunosuppressive drugs and pregnant patients were excluded from the study.

The diagnosis of ADPKD was made using the Ravine criteria (11). Data on demographics, such as age, gender, height $(\mathrm{m})$, weight $(\mathrm{kg})$, and smoking status, and duration of ADPKD, and comorbid diseases were recorded. Body mass index was calculated as weight in kilograms divided by height in meters squared. Patients using antihypertensive drugs and/or having blood pressure 140/90 $\mathrm{mmHg}$ or higher at two different measurements were considered hypertensive. Patients using oral antidiabetic drugs and/or insulin and/or with fasting blood glucose level above $126 \mathrm{mg} / \mathrm{dL}$ and/or Hemoglobin A1c level $6.5 \%$ or higher were reported as diabetic. Patients with coronary heart disease confirmed by angiography or history of coronary revascularization were accepted as having ischemic heart disease. Serum glucose, urea, creatinine, albumin, alanine transaminase, aspartate transaminase, calcium and C-reactive protein levels were measured after 12 hours of fasting with routine laboratory methods using a Beckman Coulter AU 2700 auto-analyzer following the manufacturer's instruction. Complete blood count was done using $A B X$ Penta DX120. Spot urine proteinuria was calculated by spot morning urine protein/urine creatinine ratio. Estimated glomerular filtration rate (eGFR) was calculated by the CKD epidemiology collaboration equation. The patient group was divided into two groups: eGFR below and above $60 \mathrm{~mL} / \mathrm{min} / 1.73 \mathrm{~m}^{2}$.

Jaeger Master Scobe (version 4.5, Yorba Linda, CA, USA) was used in spirometric measurements. The patients rested 15 minutes before the test. Excepted parameters were calculated automatically by inserting the data of height, weight, and gender. The tests were performed with the patient sitting upright. First, the patient was asked to take normal breaths and then take a deep breath while still using the mouthpiece, followed by a further quick, full inspiration before a full expiration. The tests were repeated three times, and the best values were recorded as forced vital capacity (FVC), forced expiratory volume in the first second (FEV1), peak expiratory flow, FEF2575 and FEV1/FVC ratio were measured. The results were classified as obstructive, restrictive or normal according to the American Thoracic Society criteria.

There was not necessary to get ethics committee approval in that time the study conducted. Written informed consent was not obtained since the study did not require an invasive procedure.

\section{Statistical Analysis}

The analysis was performed using the SPSS 17 package program (SPSS for Windows 17.0 standard 
version). Parametric values were expressed as mean \pm standard deviation, whereas nonparametric variables were presented as median (interquartile range). For comparison of two groups, the independent samples t-test was used in parameters with normal distribution and the MannWhitney $U$ test was used in parameters with abnormal distribution. The chi-square test and Fisher's exact test were used to evaluate categorical data. A $p$ value of less than 0.05 was considered statistically significant.

\section{Results}

Forty-six patients and 43 healthy volunteers were included in the study. All patients had a family history of ADPKD. Demographic, clinical and biochemical data of the patient and control groups are given in Table 1 . In the ADPKD group, 27 patients (58.7\%) had hypertension, eight (17.4\%) had ischemic heart disease and six patients (13\%) had type 2 diabetes mellitus. Hypertension was significantly more common in the patient group $(p<0.001)$.

The spirometry results of both groups are given in Table 2. The restrictive pattern was present in seven $(15.2 \%)$ patients and obstructive pattern in one (2.1\%); in the control group, restrictive pattern was present in two $(4.6 \%)$ and obstructive in one (2.3\%). There was no

\begin{tabular}{|c|c|c|c|}
\hline & $\begin{array}{l}\text { Patient group } \\
(\mathrm{n}=46)\end{array}$ & $\begin{array}{l}\text { Control group } \\
(n=43)\end{array}$ & $\mathbf{p}$ \\
\hline Male gender, n (\%) & $20(43.5)$ & $23,(53)$ & 0.34 \\
\hline Age (year) & $47.6 \pm 14$ & $41.9 \pm 13.9$ & 0.059 \\
\hline Smoking rate, n (\%) & $16(34.8)$ & $20(46.5)$ & 0.26 \\
\hline Height $(\mathrm{cm})$ & $165 \pm 9$ & $168 \pm 9$ & 0.13 \\
\hline Weight $(\mathrm{kg})$ & $75.2 \pm 13.1$ & $75.1 \pm 11.1$ & 0.94 \\
\hline BMI $\left(\mathrm{kg} / \mathrm{m}^{2}\right)$ & $27.6 \pm 4.3$ & $26.6 \pm 4$ & 0.31 \\
\hline Glucose (mg/dL) & $98 \pm 20$ & $85 \pm 14$ & 0.001 \\
\hline Urea $(\mathrm{mg} / \mathrm{dL})^{*}$ & $35(25-58)$ & $27(21-32)$ & 0.001 \\
\hline Creatinine $(\mathrm{mg} / \mathrm{dL})^{*}$ & $1.02(0.63-1.67)$ & $0.68(0.56-0.83)$ & 0.002 \\
\hline Albumin (g/dL) & $4.3 \pm 0.2$ & $4.4 \pm 0.2$ & 0.12 \\
\hline Calcium (mg/dL) & $9.4 \pm 0.4$ & $9.7 \pm 0.3$ & 0.002 \\
\hline Leukocyte $\left(\mathrm{mm}^{3}\right)$ & $6710 \pm 1521$ & $6860 \pm 1947$ & 0.68 \\
\hline Hemoglobin ( $\mathrm{g} / \mathrm{dL})$ & $12.90 \pm 1.65$ & $13.71 \pm 1.17$ & 0.009 \\
\hline Hematocrit (\%) & $38.9 \pm 4.8$ & $40.6 \pm 3.1$ & 0.056 \\
\hline Thrombocyte $\left(\mathrm{mm}^{3}\right)$ & $258.043 \pm 65.555$ & $249.279 \pm 69.959$ & 0.54 \\
\hline Proteinuria $(\mathrm{mg} / \mathrm{g})^{*}$ & $134(86-483)$ & $65(50.5-78.5)$ & 0.001 \\
\hline $\begin{array}{l}\text { eGFR } \\
\left(\mathrm{mL} / \mathrm{min} / 1.73 \mathrm{~m}^{2}\right)\end{array}$ & $77.1 \pm 43.1$ & $113.5 \pm 18.3$ & $<0.001$ \\
\hline
\end{tabular}

SD: Standard deviation, BMI: Body mass index, eGFR: Estimated glomerular filtration rate, n: Number *median (IQR 25-75) significant difference in the presence of restrictive pattern and obstructive pattern between the groups $(p=0.15$; $p=1$ ). In addition, there was no significant difference in the presence of obstructive and restrictive patterns between patients with eGFR below and above $60 \mathrm{~mL} / \mathrm{min} / 1.73 \mathrm{~m}^{2}$ (Table 3).

\section{Discussion}

ADPKD disease is a multisystem disease characterized by expansion of kidney volume and multiple cysts in kidneys and other organs $(12,13)$. While there are many studies on extrarenal manifestations of ADPKD, studies including pulmonary pathologies are limited $(4,6,14$ 17). Airway dilatation seen in ADPKD could develop by abnormal expression of polycystin in smooth muscle likewise vascular aneurysms and colonic diverticulosis (2). Expansion of renal volume and increasing intraabdominal pressure, over time, may decrease lung

\begin{tabular}{|c|c|c|c|}
\hline & $\begin{array}{l}\text { Patient group } \\
(n=46)\end{array}$ & $\begin{array}{l}\text { Control group } \\
(n=43)\end{array}$ & $p$ \\
\hline $\mathrm{FEV}_{1} \%$ & $93.6 \pm 20.9$ & $95.8 \pm 13.2$ & 0.49 \\
\hline FVC $\%$ & $93.8 \pm 19.5$ & $96.9 \pm 12.7$ & 0.04 \\
\hline $\mathrm{FEV}_{1} / \mathrm{FVC}$ & $83.8 \pm 7.3$ & $82.6 \pm 6.2$ & 0.50 \\
\hline PEF\% & $79.8 \pm 19.3$ & $86.9 \pm 20.0$ & 0.99 \\
\hline $\mathrm{MEF}_{25-75} \%$ & $81.0 \pm 24.9$ & $86.0 \pm 24.7$ & 0.64 \\
\hline $\begin{array}{l}\text { Obstrictive pattern, } \\
\mathrm{n}(\%)\end{array}$ & $1(2.1)$ & $1(2.3)$ & 1 \\
\hline $\begin{array}{l}\text { Restrictive pattern, } \mathrm{n} \\
(\%)\end{array}$ & $7(15.2)$ & $2(4.6)$ & 0.15 \\
\hline \multicolumn{4}{|c|}{$\begin{array}{l}\text { SD: Standard deviation, FVC: Forced vital capacity, FEV1: Forced expirator } \\
\text { volume in } 1 \text { second, PEF: Peak expiratory flow, MEF: Mean expiratory flow, n } \\
\text { Number }\end{array}$} \\
\hline
\end{tabular}

Table 3. The results of spirometry in patients with eGFR below and above $60 \mathrm{~mL} / \mathrm{min} / 1.73 \mathrm{~m}^{2}$ (values was given as mean $\pm \mathrm{SD}$ )

\begin{tabular}{|c|c|c|c|}
\hline & $\begin{array}{l}\text { eGFR } \geq 60 \mathrm{~mL} / \\
\min / 1.73 \mathrm{~m}^{2} \\
(\mathrm{n}=25)\end{array}$ & $\begin{array}{l}\text { eGFR }<60 \mathrm{~mL} / \\
\min / 1.73 \mathrm{~m}^{2} \\
(\mathrm{n}=21)\end{array}$ & $p$ \\
\hline $\mathrm{FEV}_{1} \%$ & $90.6 \pm 19.2$ & $96.8 \pm 22.9$ & 0.60 \\
\hline FVC\% & $91.6 \pm 17.5$ & $96.0 \pm 21.8$ & 0.25 \\
\hline $\mathrm{FEV}_{1} / \mathrm{FVC}$ & $86.2 \pm 8.1$ & $80.9 \pm 5.2$ & 0.18 \\
\hline PEF\% & $81.7 \pm 19.5$ & 77. $4 \pm 19.4$ & 0.96 \\
\hline $\mathrm{MEF}_{25-75} \%$ & $82.4 \pm 27.4$ & $80.4 \pm 22.3$ & 0.36 \\
\hline $\begin{array}{l}\text { Obstrictive } \\
\text { pattern, n (\%) }\end{array}$ & $2(8)$ & 0 & 1 \\
\hline $\begin{array}{l}\text { Restrictive } \\
\text { pattern, n (\%) }\end{array}$ & $5(20)$ & $4(19)$ & 0.12 \\
\hline \multicolumn{4}{|c|}{$\begin{array}{l}\text { SD: Standard deviation, eGFR: Estimated glomerular filtration rate, FVC: Forced } \\
\text { vital capacity, FEV1: Forced expiratory volume in } 1 \text { second, PEF: Peak expiratory } \\
\text { flow; MEF: Mean expiratory flow, n: Number }\end{array}$} \\
\hline
\end{tabular}


compliance and cause reduced FVC and also restrictive lung diseases. In addition, presence of respiratory function abnormalities is not surprising when common points in bronchiectasis pathogenesis and smooth muscle function defects found in other organs are taken into consideration. In this study, we aimed to demonstrate the effect of ADPKD on spirometry findings. In the literature, there is a limited number of studies on spirometry findings in ADPKD (6). Radiographically, presence of bronchiectasis was researched because of the idea that disruption of respiratory ciliary function may lead to bronchiectasis. Driscoll et al. (4) compared patients with ADPKD and non-ADPKD CKD patients whose etiology was different in terms of bronchiectasis detected by radiologic examination and found that the prevalence of bronchiectasis was higher in ADPKD patients. Although the disease was accompanied by bronchiectasis in patients with pulmonary involvement and pulmonary function findings of bronchiectasis with obstructive pattern, the frequency of restrictive pattern, and FVC were higher in ADPKD patients in our study $(p=0.15$ and $p=0.04$, respectively) (Table 2 ). While there was no significant difference in the incidence of restrictive patterns, the decrease in FVC, which is one of the most critical findings of restrictive lung diseases, supported the hypothesis of the effect of increased intraabdominal pressure on lung volume capacity. In a study conducted by Moua et al. (6), pulmonary function test was similar in patients with ADPKD and patients with CKD.

Patients with eGFR below and higher than $60 \mathrm{~mL} /$ $\mathrm{min} / 1.73 \mathrm{~m}^{2}$ were compared with each other, and we found no relationship between kidney function test and pulmonary function test (Table 3). The reason for not determining the relationship between them may be due to the number of participants or the lack of renal volume in the study. The mean eGFR was $35.4 \pm 14.3$ in patients with an eGFR $<60$. Further studies on this subject are needed.

\section{Study Limitations}

It is obvious that if the study has been done with larger patient participation as well as kidney volume assessment, clearer data would be obtained.

\section{Conclusion}

Although the frequency of restrictive pattern was not significantly higher, FVC was significantly lower in ADPKD patients than in controls. This may reflect the indirect effects of enlarged kidneys. Further detailed studies, including renal volume, are needed.

\section{Authorship Contribution}

Concept: T.E.Ö, F.K. Design: E.C., M.G. Data Collection or Processing: T.E.Ö., F.K. Analysis or Interpretation: S.Ö.,
Z.K., E.C., B.D. and G.Ç. Literature Search: M.G., M.S., A.Ş. Writing: T.E.Ö., F.K.

Conflict of Interest: No conflict of interest was declared by the authors.

Financial Disclosure: The authors declared that this study received no financial support.

\section{References}

1. Davies F, Coles GA, Harper PS, et al. Polycystic kidney disease re-evaluated: a population-based study. Q J Med 1991;79:47785.

2. Torres VE, Harris PC, Pirson Y. Autosomal dominant polycystic kidney disease. Lancet 2007;369:1287-301.

3. Luciano RL, Dahl NK. Extra-renal manifestations of autosomal dominant polycystic kidney disease (ADPKD): considerations for routine screening and management. Nephrol Dial Transplant 2014;29:247-54.

4. Driscoll JA, Bhalla $S$, Liapis $H$, et al. Autosomal dominant polycystic kidney disease is associated with an increased prevalence of radiographic bronchiectasis. Chest 2008;133:1181-8.

5. Jain R, Javidan-Nejad C, Alexander-Brett J, et al. Sensory functions of motile cilia and implication for bronchiectasis. Front Biosci (Schol Ed) 2012;4:1088-98.

6. Moua T, Zand L, Hartman RP, et al. Radiologic and clinical bronchiectasis associated with autosomal dominant polycystic kidney disease. PLoS One 2014;9:e93674.

7. Wu J, Du H, Wang $X$, et al. Characterization of primary cilia in human airway smooth muscle cells. Chest 2009;136:561-70.

8. Ecder T, Schrier RW. Hypertension in autosomal-dominant polycystic kidney disease: early occurrence and unique aspects. J Am Soc Nephrol 2001;12:194-200.

9. Gabow PA, Chapman AB, Johnson AM, et al. Renal structure and hypertension in autosomal dominant polycystic kidney disease. Kidney Int 1990;38:1177-80.

10. Drayer JI, Weber MA, DeYoung JL. BP as a determinant of cardiac left ventricular muscle mass. Arch Intern Med 1983; 143:90-2.

11. Ravine $D$, Gibson RN, Walker RG, et al. Evaluation of ultrasonographic diagnostic criteria for autosomal dominant polycystic kidney disease. Lancet 1994;343:824-7.

12. Singla V, Reiter JF. The primary cilium as the cell's antenna: signaling at a sensory organelle. Science 2006;313:629-33.

13. Xu C, Rossetti S, Jiang L, et al. Human ADPKD primary cyst epithelial cells with a novel, single codon deletion in the PKD1 gene exhibit defective ciliary polycystin localization and loss of flow-induced Ca2+ signaling. Am J Physiol Renal Physiol 2007;292:F930-45.

14. Ibrahim WH, Rasoul FA. Pulmonary manifestations of adult polycystic kidney disease: case report and literature review. Ibnosina J Med Biomed Sci 2015;7:169-72. 
Özler et al. The Effect of ADPKD on Spirometric Parameters

15. Luciano RL, Dahl NK. Extra-renal manifestations of autosomal dominant polycystic kidney disease (ADPKD): considerations for routine screening and management. Nephrol Dialysis Transplant 2014;29:247-54.

16. Li HY, Cosgrove GP, Swigris JJ. Dyspnea in a 43-year-old woman with polycystic kidney disease. Chest 2009;135:238-43.
17. Shanmuganathan A, Rao UK, Chandrasekharan A, Thanasekaraan LD, Palanisamy C, Thanasekaraan V. Recurrent pneumothorax associated with polycystic kidney disease. Indian J Chest Dis Allied Sci 2008;50:233-5. 